\title{
BMJ Open Female genital cutting in Malaysia: a mixed-methods study
}

To cite: Rashid A, Iguchi Y. Female genital cutting in Malaysia: a mixedmethods study. BMJ Open 2019;9:e025078. doi:10.1136/ bmjopen-2018-025078

- Prepublication history and additional material for this paper are available online. To view these files, please visit the journal online (http://dx.doi. org/10.1136/bmjopen-2018025078).

Received 3 July 2018 Revised 16 February 2019 Accepted 5 March 2019

\section{Check for updates}

(c) Author(s) (or their employer(s)) 2019. Re-use permitted under CC BY-NC. No commercial re-use. See rights and permissions. Published by BMJ.

${ }^{1}$ Public Health Medicine, RCSI \& UCD Malaysia Campus, George Town, Malaysia

${ }^{2}$ College of Asia Pacific Studies, Ritsumeikan Asia Pacific University, Beppu, Japan

Correspondence to Professor Abdul Rashid; rashid@rcsiucd.edu.my

\author{
Abdul Rashid, ${ }^{1}$ Yufu Iguchi ${ }^{2}$
}

\begin{abstract}
Objective This study aimed to understand the reasons for the practice by the Muslim community, traditional practitioners and the views of religious scholars as well as the medicalisation trend of the practice of female genital cutting (FGC).

Design This is a mixed-method (qualitative and quantitative) study. A questionnaire was created and used by three trained research assistants for the quantitative component of the study. The qualitative component of the study included in-depth interviews and focus group interviews.
\end{abstract}

Setting This study was conducted in rural areas of two states in the Northern Peninsular Malaysia.

Participants Due to the sensitive nature of the study, the study sample was chosen using a snowball sampling method. Two of the three Northern states Mufti's approached consented to participate in the study. Results Quantitative: There were 605 participants, most had undergone FGC (99.3\%), were in the opinion FGC is compulsory in Islam (87.6\%) and wanted FGC to continue (99.3\%). Older respondents had FGC conducted by traditional midwives $\left(X^{2}=59.13, p<0.001\right)$ and younger age groups preferred medical doctors $\left(X^{2}=32.96, p<0.001\right)$ and would permit doctors $\left(X^{2}=29.17, p<0.001\right)$ to conduct $F G C$ on their children. These findings suggest a medicalisation trend. Regression analysis showed the odds of FGC conducted by traditional midwives and nurses and trained midwives compared with medical doctors was 1.07 (1.05; $1.09)$ and $1.04(1.01 ; 1.06)$, respectively. For every 1 -year decrease in age, the odds of participants deciding medical doctors should perform FGC as compared with traditional midwives increase by 1.61. Qualitative: Focus group discussions showed most believed that FGC is compulsory in Islam but most traditional practitioners and the Mufti's stated that FGC is not compulsory in Islam.

Conclusion Almost everyone in the community believed FGC is compulsory in Islam and wanted the practice to continue, whereas the traditional practitioners and more importantly the Mufti's, who are responsible in issuing religious edicts, say it is not a religious requirement.

\section{INTRODUCTION}

Female genital mutilation/cutting (FGM/C) is controversial, because communities that practise it equate it with religion and culture whereas those who oppose it label it as a 'harmful traditional practice', harmful both physically and mentally, and also a human rights violation. ${ }^{1}$ The practice is most
Strengths and limitations of this study

- The purposive sampling method used limits the generalisation of the findings.

- Limited number of traditional practitioners interviewed is also a limitation.

- The information garnered in this study can be used as an important strategy to eliminate female genital cutting (FGC) in Malaysia.

- First study to use mixed-methods study design in Malaysia on FGC.

- Mixed method gives better insight to the study topic.

prevalent in the African countries, especially Egypt. ${ }^{2}$ In 2013, Unicef reported that an estimated 125 million girls and women have been cut in 29 countries in Africa and the Middle East and 30 million more are at risk of being cut in the coming decade. ${ }^{2}$ In 2012, the United Nations (UN) general assembly adopted a resolution to intensify global efforts to eliminate FGC. ${ }^{2}$

FGC is a name given to a wide range of practices by different practitioners using different procedures with different consequences. ${ }^{3}$ The term FGC is used in this paper instead of FGM, which the authors believe is not only controversial but culturally insensitive for the minimally practised cutting $^{14-6}$ done in Malaysia. The term FGM was adopted in 1990 by the Inter African committee on traditional practices affecting the health of women and children, and in 1991 WHO recommended the UN to adopt it. $^{2}$ The term FGM has a negative connotation and does not help in the process of eradication of the practice ${ }^{7}$ because it has been associated with female subjugation, ${ }^{89}$ barbarism, ${ }^{7-9}$ violence and discrimination towards women and a human rights violation. ${ }^{6}$ The term FGM emphasises the worst possible extent of the procedure and the intentions of those carrying out the procedure. Because there are many reasons, including purity, tradition and religion, which have been associated with the practice, ${ }^{1}$ some practitioners have resorted to use other 
terminologies including 'female genital surgeries', ${ }^{1}$ 'Female Genital Operations', ${ }^{10}$ 'female genital alteration' ${ }^{6}$ and 'female circumcision'. ${ }^{11}$ In Malaysia, ${ }^{12}$ Indonesia ${ }^{13}{ }^{14}$ and Thailand, ${ }^{15}$ the practice is called 'sunat', taken from the Arabic word 'sunah', the practices and sayings of the Prophet Muhammad which is a recommended or an advisable action. ${ }^{14}$ But complying with the UN's recommendation the term FGG is used instead of 'sunat', ${ }^{11-131516}$ clitoridectomy, subincision, ${ }^{17}$ female genital operations ${ }^{1}$ or female genital alterations. ${ }^{6}$ There are no laws concerning FGC in Malaysia and the Malaysian Medical Council is silent on this subject. The department of religious affairs of Malaysia had issued a fatwa (opinions on Islamic law) in 2009 that FGC is wajib (mandatory) for females with the exception of medical reasons. However, a fatwa is not legally binding.

FGC predates Islam and although FGC is not solely practised in Islamic communities, it is often linked to Islam. ${ }^{218}$ FGC occurs across different ethnicities, cultures and socioeconomic classes. ${ }^{19-21}$ Although the practice is mostly prevalent in African and Middle Eastern countries, FGC is also common among Muslim communities in the east including Malaysia, Indonesia and Thailand ${ }^{11-1322}$ who follow the shafii school of Islamic law in sunni Islam. Because of migration, there have been reports of FGC in Europe, North America and Australia. ${ }^{52324}$ It is important to note that although the practice is prevalent across the continents, the extent and type of cutting is not the same in different communities. Communities in the African countries practise the most traumatic and damaging kind $^{1125}$ as compared with that in Southeast Asia (SEA).

Most of the cutting is usually conducted by traditional healers, who do not have any medical training, without anaesthesia and sterilisation ${ }^{26}$ on girls of all ages, but more commonly ages $0-15 .{ }^{314} 17$ But due to the campaigns on the risks of unsanitary environment, more FGC is beginning to be conducted by health professionals in clinics. ${ }^{12728}$

Different communities have cited different reasons for the practice including religion, passage to womanhood, hygiene, social identity (norm), tradition, culture, health, controlling or enhancing women's sexuality, protection of virginity, peer pressure, socio economic status and marriageability. ${ }^{2} 47252729-33$

The different types of the practice listed as FGC by WHO in 1995 and updated in 2007 include $^{2}$

Type I: Also called 'clitoridectomy' is the partial or total removal of the clitoris and/or the prepuce.

Type II: Partial of the total removal of the clitoris and labia minora with or without excision of the labia majora.

Type III: Narrowing the vaginal orifice by cutting and bringing together the labia minora and/or the labia majora to create a type of seal, with or without excision of the clitoris. In some instances, the cut edges of the labia are stitched together, which is referred to as infibulation.

Type IV: All other harmful procedures to the female genitalia for non-medical purposes, for example, pricking, piercing, incising, scraping and cauterisation to draw blood but no removal of tissue and no permanent alteration of the external genitalia.

In Malaysia, the practice falls under type IV, because the practice here involves nicking the tip of the clitoris and teasing out a piece of the tissue using a penknife or razor on children as young as one or 2 months old and a drop of blood is considered as a requirement for the fulfilment of the ritual (type IV). ${ }^{12}{ }^{16}$ Burden of FGC include shortterm and long-term complications ranging from pain and injury to adjacent tissue, to more serious complications including haemorrhage and shock, urinary retention, acute and chronic infections, difficulty in passing urine, urinary tract infections, pelvic infections, infertility, keloid scars, abscess and cyst, menstrual difficulties, dyspareunia and problems with pregnancy and childbirth, sexual, mental and social consequences. ${ }^{1}$ Not all forms of FGC carry the same risks. ${ }^{6}$ Most of the short-term and long-term complications from FGC are related to types I-III as well as the skill of the practitioner. ${ }^{1} 41821263234$ However, a review of literature conducted did not show strong evidence that the practice poses a great danger to women's health. Complications from the more serious forms of FGC have been reported as $1 \%$ for serious and $1 \%-18 \%$ for less serious complications. ${ }^{1}$ Studies conducted in Indonesia, Malaysia and Singapore have reported no significant health-related risks from the procedure and physical examination failed to show any evidence of injury to the clitoris nor the labia and no signs of excised tissue. ${ }^{9111216}$ The practice in SEA is very minimal and has been compared with the practice of ear piercing of female infants which in Indonesia is offered as a package along with FGC. ${ }^{11} 2235$ The practice has no lasting side effect and some women are even unaware if they had undergone FGC. ${ }^{11}$ In some, who remembered the FGC described it as a brief sharp pain comparable to ear piercing and in the worst case the discomfort lasted for about 2 days ${ }^{11}$ but all were able to walk the following day. ${ }^{22}{ }^{35}$ No evidence is found to show that FGC destroys sexual pleasure in SEA. ${ }^{120}$ There is no reported loss of libido in studies conducted in Indonesia, ${ }^{9}$ Singapore ${ }^{11}$ or Malaysian ${ }^{12}$ among women who had undergone FGC.

Despite 30 years of intervention, including criminalisation of the practice, there is no significant reduction in FGC, ${ }^{6} 36$ probably because of the strong religious and cultural values placed on the practice. The communities that practise FGC consider interventions as culturally insensitive, ethnocentric, racist and over sensationalised ${ }^{6}$ making them defensive, distrustful and feeling it as an insult to their parents, community and ancestry by portraying them as abusers and uncivilised. ${ }^{34}$

It is important to understand the practice and factors which are related to it in order to comprehend the influences that can help stop the practice. ${ }^{2}$ Because the practice is related to cultural identity, it is important to understand the reasons for the practice in each culture. This information can be used to form culturally and religiously sensitive interventions. ${ }^{20}$ Most studies relating to FGC are conducted in African countries where the 
practice is more traumatic and damaging to health ${ }^{11}$ and by researchers who do not live within these communities. Not many studies have been conducted in SEA where the practice is not as harmful as that in Africa. ${ }^{13}$ Because there are no nationally representative data on FGC in Malaysia ${ }^{2}$ and very few published articles concerning the practice of FGC in Malaysia, this study was conducted to understand the reasons for the practice by the community and traditional practitioners and the views of the religious scholars. The objectives of the study are to determine the:

1. Prevalence and type of FGC.

2. Age FGC conducted.

3. Medicalisation of the practice.

4. Reasons for the practice and its continuation.

The authors hope the information garnered can be used for interventional strategies.

\section{METHODS}

\section{Study design and location}

This mixed-method (qualitative and quantitative) study was conducted among women 18 years and older in the rural areas of Kedah and Penang, 2 of 14 states located in the Northern region of Peninsular Malaysia. Because only Malay Muslims are known to practise FGC in Malaysia, the study location was chosen on the basis that the population in these rural villages is majority Malay Muslims. The qualitative component of the study included in-depth interviews with traditional midwives (known as Mak Bidan in Malay) practising or had practised FGC in these two states. Focus group discussions were also conducted in one conveniently selected village. Two in-depth interviews were held with the Mufti, who is a religious scholar or jurist qualified to issue Islamic legal opinions. In Malaysia, each state has one Mufti as religion is within the jurisdiction of the state and not the federal government of two Northern states.

\section{Tools}

Because no such study has been conducted in Malaysia, a questionnaire (available as online supplementary file 1) was created and used by three trained research assistants in the participants' homes or place of work. Questions for the quantitative component of the study included age, occupation, marital status, level of education, questions on their knowledge on whether female circumcision was allowed by law and religion, who circumcised the participant, opinion on who should conduct and who they will or have allowed to perform FGC on their daughters and the reasons and perceived benefits of FGC. For the qualitative part, in-depth interviews with the 'Mak Bidans' were conducted using a semistructured interview guide. Similarly, the in-depth interviews with the Mufti's were conducted using a guide focusing on the religious perspective of FGC. Focus group interviews were conducted on three groups, younger women aged 18-45, older women aged 45 and above and on a group of adult men who were married. The focus group discussions were also conducted using a semistructured interview guide. The interviews focused on the reason, decision-making, practice and continuity of the practice.

\section{Population}

Due to the sensitive nature of the study, the study sample for the quantitative part of the study was chosen conveniently using a snowball sampling method. We approached the villagers who had shown interest in participating and requested each of them to recommend someone they knew who would be interested in participating in the study, the research assistants then called each of them to ask if they were interested in participating in the study. This went on until the required sample size was achieved. For the qualitative part of the study, the 'Mak Bidans' were also sampled using snowball sampling method. The names of the Mak Bidans' were given by the participants in the quantitative part of the study, the 'Mak Bidans' were then asked to recommend other 'Mak Bidans' who were or had practised FGC. They were then called up and asked if they would be willing to participate in this study. The participants for the focus group discussions were chosen based on their willingness to be part of the discussions and on their talkative personality. The participants from the female focus groups had also participated in the quantitative part of the study. The male members were recruited by putting up posters and issuing pamphlets concerning the recruitment of subjects for the focus group discussion. Two of the three Northern states Muftis who were approached, consented to participate in the study.

\section{Sampling}

Considering the vast majority of Muslim women in Malaysia practice FGC, a sample size of approximately 450 participants were required for a margin of error of $5 \%$ with a sample proportion of 0.5 . Each of the three research assistants was given the task of getting 200 participants from different districts in the two states with the anticipation of drop-outs. In total 654 participants consented but due to incomplete data, only 605 participants' data were used for analysis. For the qualitative part of the study, seven participants were selected for each focus group discussion and eight in-depth interviews were conducted with the 'Mak Bidans'.

\section{Analysis}

Quantitative (available as online supplementary file 2): Data were analysed using SPSS V.18 and presented descriptively in tables and graphs. $\chi^{2}$ test was used to determine the statistically significant association of the different age groups with the persons who performed FGC on them, who they thought should conduct FGC and who the participants have or will permit to conduct FGC on their children. Multinomial logistic regression was performed to find the association of age as the independent variable with who performed FGC on them, who they think should perform FGC and who they will permit to perform 
FGC on their children to show a trend in medicalisation. For this multinomial analysis, the variable 'doctors' was used as reference for the analysis of who performed FGC and traditional midwives was used as the reference for who they will permit to perform and who the participants think should perform FGC. Figures are presented to show the trend in medicalisation.

Qualitative: Qualitative data were collected using a structured questionnaire. Data were collected until saturation of information was achieved. Saturation of data was considered to have achieved when no new information was availed from the respondents. The data were then transcribed manually, organised, coded and recoded. The clustered codes were elicited as common themes by the team comprising the investigators and research assistants.

\section{Ethics}

This study was ethically conducted with all the participants providing informed consent. The anonymity of the participants is assured, each participant was assigned a unique code.

\section{Patient and public involvement}

No patients were recruited for the study. This study involved recruitment of women aged 18 years and older in the rural areas of 2 of 14 states located in the Northern region of Peninsular Malaysia. Snowball method was used to recruit traditional midwives (Mak Bidan) practising or had practised FGG in the two states for in-depth interviews and two of the three Mufti's of the Northern states approached consented to be interviewed. The findings of the study have been informed to the participants by post. The authors would like to thank all the participants for their time and participation.

\section{RESULTS}

\section{Quantitative}

As shown in tables 1 and 2, a total of 605 participants responded, the majority were in the age group 26-40 $(40.0 \%)$, married $(54.7 \%)$, having tertiary education $(57.9 \%)$ and employed full time $(53.1 \%)$. The overwhelming majority was in the opinion that FGC is compulsory in Islam (87.6\%), legal in Malaysia (92.1\%) and believed that FGC is practised by all the Muslim sects $(81.8 \%)$. Almost everyone had undergone FGC (99.3\%). The median age of the participants who underwent FGC was 6 years old, which is also the median age the participants felt was the suitable age FGC should be conducted. Almost all $(99.3 \%)$ of the participants wanted FGC to continue. High-profile religious preachers $(34.5 \%)$ followed by medical practitioners $(30.9 \%)$ were the persons the participants would trust the most relating to information concerning FGC.

As shown in figure 1, the common reason for FGC is hygiene $(25.0 \%)$, health $(24.0 \%)$ and religion $(23.0 \%)$. As shown in figure 2, the main reason for choosing traditional practitioner to conduct FGC is because of no side
Table 1 Demographic variables of participants in the quantitative part $(n=605)$

\begin{tabular}{lrr}
\hline Variable & N & Percentage \\
\hline Age & 194 & 32.1 \\
\hline$<26$ & 242 & 40.0 \\
$26-40$ & 152 & 25.1 \\
\hline $41-60$ & 17 & 2.8 \\
\hline$>60$ & & \\
Marital status & 331 & 54.7 \\
$\quad$ Married & 19 & 3.1 \\
\hline Divorce & 14 & 2.3 \\
\hline Widow & 241 & 39.8 \\
\hline Single & & \\
\hline Highest level of education & 3 & 0.5 \\
\hline Illiterate & 1 & 0.2 \\
\hline Informal & 26 & 4.3 \\
\hline Primary school & 225 & 37.2 \\
\hline Secondary school & 350 & 57.9 \\
\hline Tertiary & & \\
\hline Occupation & 321 & 53.1 \\
\hline Full time & 8.6 \\
\hline Part time & 38.3 \\
\hline Unemployed & 232 & \\
\hline
\end{tabular}

effects $(82.6 \%)$ and the main reason for choosing a clinic is because of cleanliness $(63.6 \%)$ and expertise $(60.5 \%)$.

As shown in table 3, more older respondents had FGC conducted by traditional midwives as compared with nurses and trained midwives and doctors $\left(\mathrm{X}^{2}=59.13, \mathrm{p}<0.001\right)$. Younger age groups preferred medical doctors to perform FGC (who should perform FGC) $\left(\mathrm{X}^{2}=32.96, \mathrm{p}<0.001\right)$. Similarly the younger age group would permit doctors to conduct FGC on them or their children as compared with older respondents $\left(\mathrm{X}^{2}=29.17, \mathrm{p}<0.001\right)$. The trend in medicalisation can be visualised in figures 3-5. More older respondents had FGC performed on them by traditional midwives as compared with younger respondents (figure 3) and more younger respondents were in the opinion that doctors should conduct FGC as compared with older respondent who preferred traditional midwives (figure 4) and more respondents from the younger group would permit doctors to perform FGC on their children as compared with the older respondents (figure 5).

Regression analysis showed (table 4) for every 1-year increase in age, the odds of FGC conducted by traditional midwives and nurse and trained midwives compared with medical doctors was $1.07(1.05 ; 1.09)$ and $1.04(1.01 ; 1.06)$, respectively. For every 1-year decrease in age, the odds of participants deciding medical doctors should perform of FGC as compared with traditional midwives increased by $1.61(1 / 0.62)$. The association of who will be permitted to perform FGC with age was not statistically significant for 
Table 2 Quantitative responses to female genital cutting (FGC) related variables $(n=605)$

\begin{tabular}{|c|c|c|}
\hline Variable & $\mathbf{N}$ & Percentage \\
\hline \multicolumn{3}{|c|}{$\begin{array}{l}\text { FGC is compulsory in } \\
\text { Islam }\end{array}$} \\
\hline Yes & 530 & 87.6 \\
\hline No & 75 & 12.4 \\
\hline \multicolumn{3}{|c|}{ FGC is legal in Malaysia } \\
\hline Yes & 557 & 92.1 \\
\hline No & 48 & 7.9 \\
\hline \multicolumn{3}{|c|}{$\begin{array}{l}\text { FGC is conducted by all } \\
\text { Islamic sects }\end{array}$} \\
\hline Yes & 495 & 81.8 \\
\hline No & 110 & 18.2 \\
\hline \multicolumn{3}{|c|}{ Best age for FGC } \\
\hline & \multicolumn{2}{|c|}{ Median-6years } \\
\hline & \multicolumn{2}{|c|}{$\begin{array}{l}\text { Range-birth to } \\
24 \text { years }\end{array}$} \\
\hline \multicolumn{3}{|c|}{ Did you undergo FGC } \\
\hline Yes & 601 & 99.3 \\
\hline No & 4 & 0.7 \\
\hline \multicolumn{3}{|c|}{ Age FGC done } \\
\hline & \multicolumn{2}{|c|}{ Median -6 years } \\
\hline & \multicolumn{2}{|c|}{$\begin{array}{l}\text { Range - birth to } \\
30 \text { years }\end{array}$} \\
\hline \multicolumn{3}{|c|}{ Should FGC continue? } \\
\hline Yes & 601 & 99.3 \\
\hline No & 4 & 0.7 \\
\hline
\end{tabular}

Who you trust the most

on information concerning

FGC

\begin{tabular}{llc}
\hline Local religious leader & 110 & 18.2 \\
\hline $\begin{array}{l}\text { Local religious teacher } \\
\text { High-profile religious }\end{array}$ & 73 & 12.1 \\
preacher & 209 & 34.5 \\
$\begin{array}{l}\text { Representative from } \\
\text { state religious office }\end{array}$ & 16 & 2.6 \\
\hline $\begin{array}{l}\text { Academician } \\
\text { Non Governmental }\end{array}$ & 10 & 1.7 \\
$\begin{array}{l}\text { Organisation } \\
\text { Politician }\end{array}$ & 0 & 0 \\
\hline Medical practitioner & 187 & 0 \\
\hline
\end{tabular}

medical doctors (1.01, 95\% CI 0.99 to 1.03 ) and nurses and trained midwives $(1.006,95 \%$ CI 0.99 to 1.02$)$.

\section{Qualitative}

Table 5 shows the demographics of the participants in the qualitative part of the study, the traditional midwives were all married, unemployed and the age ranged from 68 to 83 years. The participants of the young female

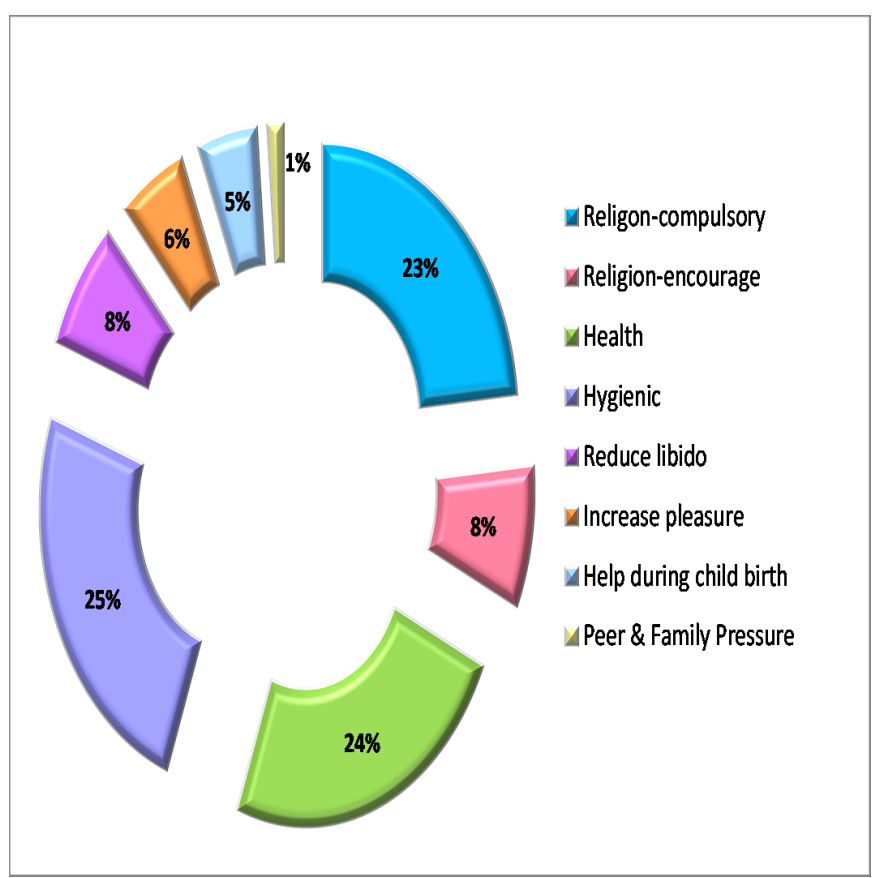

Figure 1 Common reasons for doing FGC. FGC, female genital cutting.

focus group discussion were all married except one and most were housewives $(n=5)$, with the age range from 30 to 44 years. The participants of the older female focus group discussion were all married and unemployed and the age ranged from 62 to 70 years. Participants of the male focus group discussion were all married and mostly unemployed $(n=5)$ with the age range from 48 to 77 years.

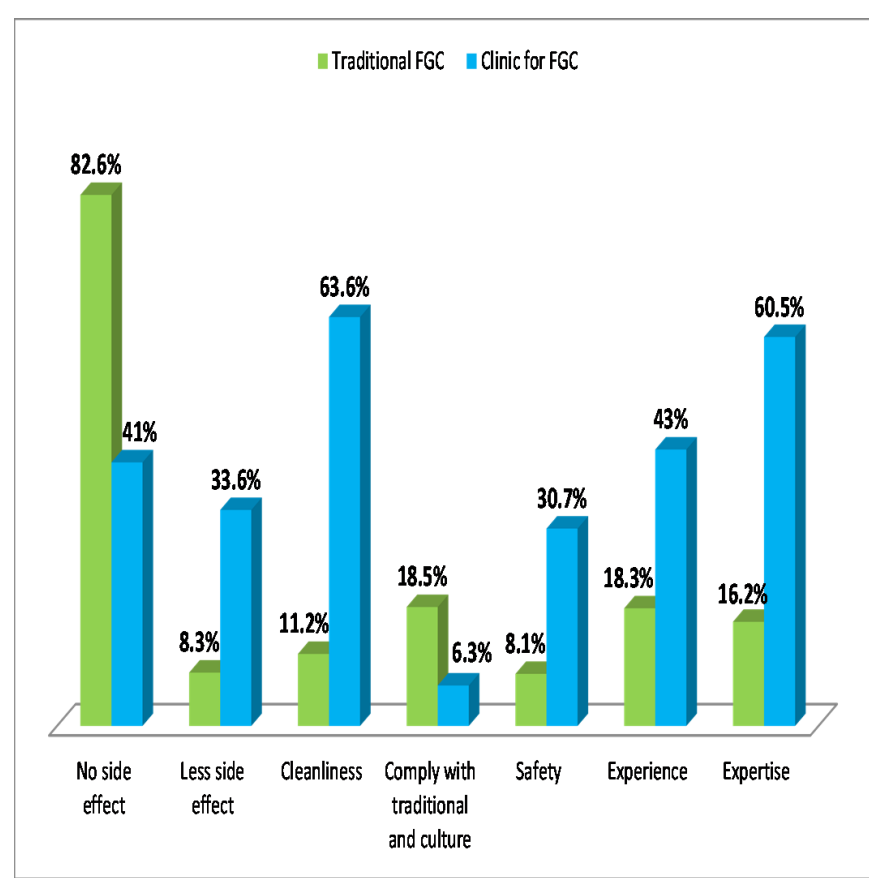

Figure 2 Reasons for choosing traditional practitioner or clinic. FGC, female genital cutting. 
Table 3 Association of female genital cutting (FGC) practitioners and age

\begin{tabular}{|c|c|c|c|c|}
\hline Age & Traditional midwives & $\begin{array}{l}\text { Nurses and } \\
\text { trained midwives }\end{array}$ & Doctor & $\mathrm{X}^{2} / \mathrm{P}$ value \\
\hline \multicolumn{5}{|c|}{ Who performed FGC (n=601, \%) } \\
\hline $26-40$ & $150(62.5)$ & $34(14.2)$ & $56(23.3)$ & \multirow{2}{*}{$59.13 /<0.001$} \\
\hline $41-60$ & $116(77.3)$ & $12(8.0)$ & $22(14.7)$ & \\
\hline \multicolumn{5}{|c|}{ Who should perform FGC ( $n=605, \%)$} \\
\hline$<26$ & $33(17.0)$ & $43(22.2)$ & $118(60.8)$ & \multirow[t]{4}{*}{$32.96 /<0.001$} \\
\hline $26-40$ & $38(15.7)$ & $52(21.5)$ & $152(62.8)$ & \\
\hline $41-60$ & $37(24.3)$ & $37(24.3)$ & $78(51.4)$ & \\
\hline$>60$ & $11(64.7)$ & $5(29.4)$ & $1(5.9)$ & \\
\hline $41-60$ & $32(21.1)$ & $33(21.7)$ & $87(57.2)$ & \multirow{2}{*}{$29.17 /<0.001$} \\
\hline$>60$ & $9(52.9)$ & $4(23.5)$ & $4(23.6)$ & \\
\hline
\end{tabular}

\section{Several themes were teased out of the interviews}

Procedure and religious requirements

All the Mak Bidans interviewed in this study agreed that the procedure may differ but all mentioned the need for a drop of blood for the fulfilment of the ritual, said one Mak Bidan '...scrape slowly until a drop of blood...no more than a drop of (blood) but must have a drop of blood'.

Many different tools were mentioned during the interviews. The 'Mak Bidans' interviewed in this study mentioned nail clippers, scissors and blade as the tools of

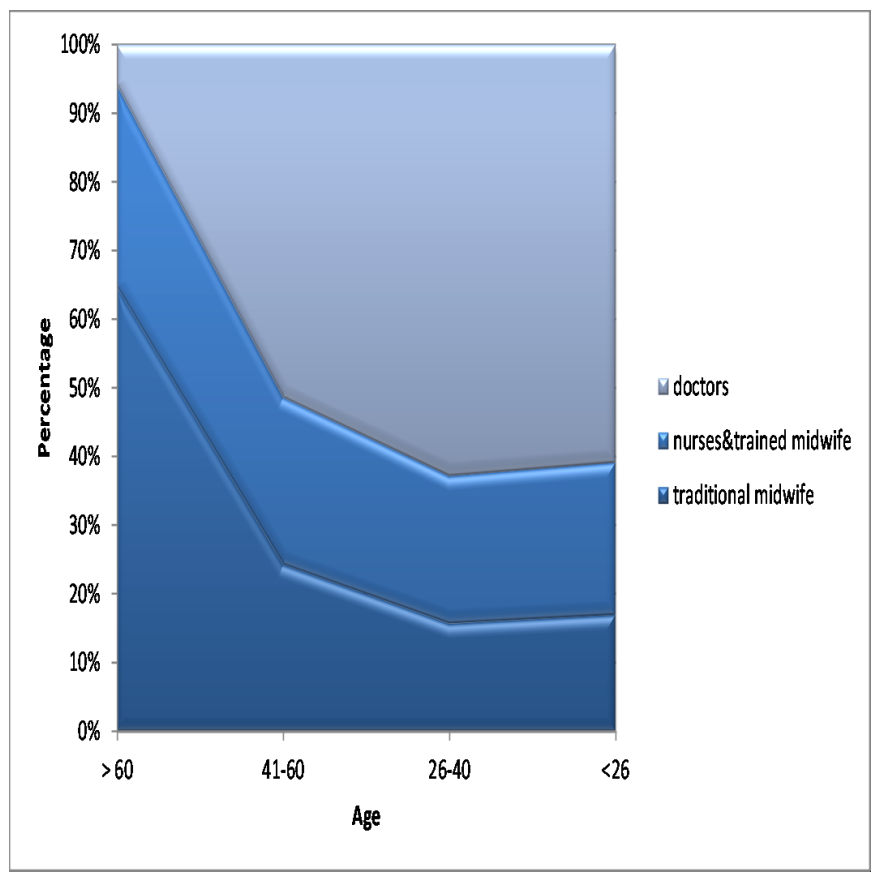

Figure 3 Who performed FGC. FGC, female genital cutting. their trade. Only one 'Mak Bidan' used coins 'I take two coins and pinch off the tissue'.

\section{A religious practice}

Findings of the quantitative component of the study found religion as the main reason for FGC. This was contradictory to what the traditional midwives believed. During the interviews with the 'Mak Bidans', only one stated confidently that it is a requirement in religion while others mentioned tradition and cleanliness as the reasons for

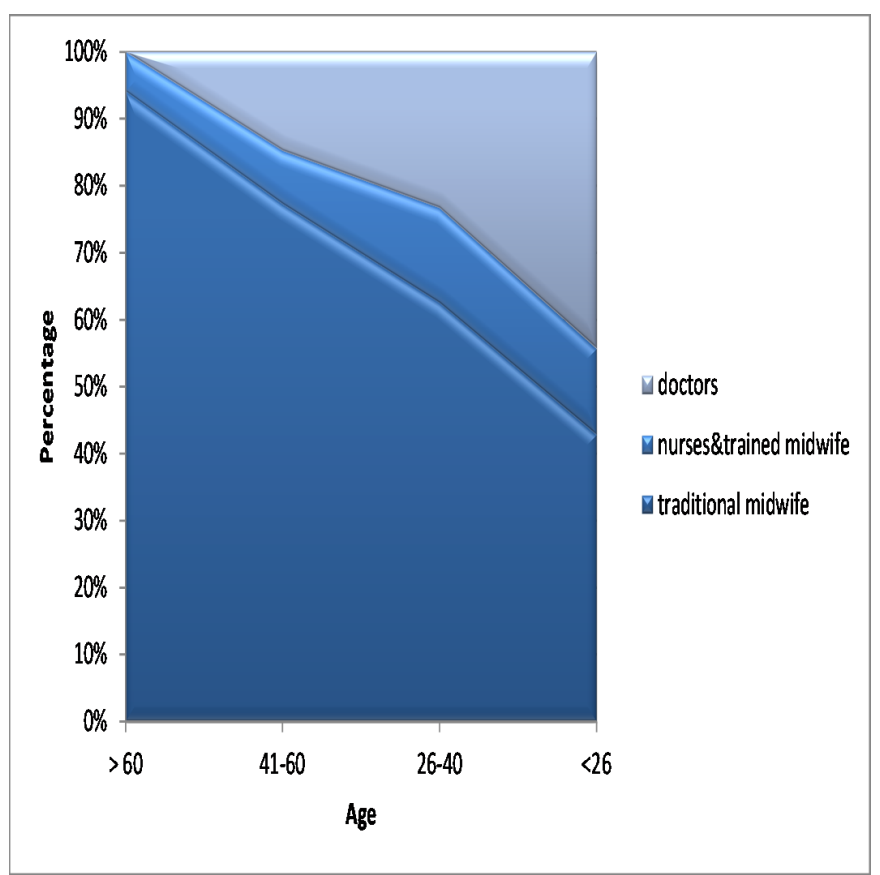

Figure 4 Who should perform FGC. FGC, female genital cutting. 


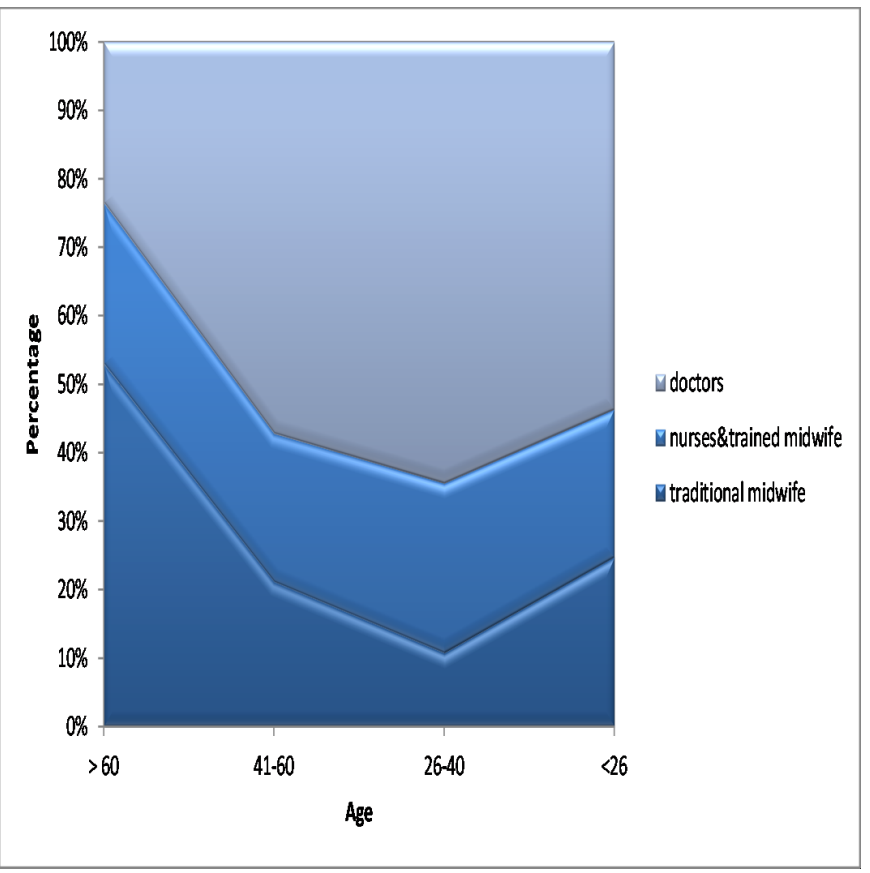

Figure 5 Who will be permitted to perform FGC on respondent's children. FGC, female genital cutting.

FGC. One 'Mak Bidan' who still conducts FGC said 'I am not sure why we do it, possibly because of a requirement in Islam... anyway, it's been done since generations'.

Another 'Mak Bidan' said 'it's not compulsory....it's up to them, if one wants to do, do it, if not don't....it's not a religious requirement but a tradition'.

However, during the focus group discussions, religion was consistently mentioned. A member of the younger women's focus group said 'according to Islam, it's a must, cannot say no. Must do...' While a member of the older women's focus group said 'this is one of the ways to determine (differentiate) a Muslim and a non-Muslim'.

When told that majority of the study sample felt that it was compulsory in Islam, both the Muftis interviewed strongly disagreed. One was aghast and said 'no, no, no not true' while the other responded angrily 'we don't know (recognize) that kind of Islam'.... if we say that it is 'wajib' (obligatory),... impossible....thousands of woman converted to Islam during the prophet's time and none of them were told to circumcise'.

During the interview with the Muftis, one felt that although it is not compulsory but because a large proportion of the 'Ulema' are in the opinion it is acceptable for the practice to continue, he has no objection for its continuation. However, another mufti was more blunt '...there are many practices which have nothing to do with religion like shaving the child's head...but they mix everything. The procedure (female circumcision) done in clinic or hospital too is not consistent because there is no manual, so why do it? For me, I want to say no need for this country'... 'bottom line is that if it's for a medical reason they can do it but that has nothing to do with religion'...'We are going to do that (issue a fatwa against female circumcision) in ..... (his state), we will issue a fatwa and we will make it public.... Tell the people that you don't need to do that in our country, unless you have a medical condition'.

\section{Medicalisation}

All persons interviews in general preferred medical practitioners. This could be related to hygiene and the dwindling number of traditional midwives. But because of the association of FGC to religion and culture, there is a wish for 'Mak Bidans' to do it

Participant from the older women's focus group said, 'I prefer doctor because it's easier, besides it's not easy to find a Mak Bidan that will want to do'.

From the younger women's focus group

"I prefer a doctor because it's easier besides it's not easy to find a Mak Bidan that will want to do circumcision'

'Doctors, because its hygienic,... they are very careful'

Table 4 Regression analysis of age and female genital cutting (FGC)

\begin{tabular}{|c|c|c|c|c|c|}
\hline & B & SD & Wald & Sig & OR (95\% Cl) \\
\hline \multicolumn{6}{|l|}{ Who performed FGC $(n=601)$} \\
\hline \multicolumn{6}{|l|}{ Ref: doctors } \\
\hline Nurse and trained midwives & 0.036 & 0.013 & 7.78 & 0.005 & 1.04 (1.01 to 1.06$)$ \\
\hline \multicolumn{6}{|c|}{ Who should perform FGC $(n=605)$} \\
\hline Medical doctors & -0.477 & 0.129 & 13.63 & $<0.001$ & $0.62(0.48$ to 0.79$)$ \\
\hline Nurse and trained midwives & -0.270 & 0.150 & 3.23 & 0.73 & $0.76(0.57$ to 0.03$)$ \\
\hline \multicolumn{6}{|c|}{ Who will be permitted to perform FGC ( $n=605)$} \\
\hline \multicolumn{6}{|c|}{ Ref: traditional midwives } \\
\hline Medical doctors & 0.012 & 0.008 & 2.07 & 0.150 & 0.99 (0.99 to 1.004$)$ \\
\hline
\end{tabular}


Table 5 Characteristic of participants in the qualitative part of the study

\begin{tabular}{|c|c|c|c|}
\hline Participants & Age & Marital status & Employment \\
\hline Traditional midwives & $\begin{array}{l}\text { Range: } 68-83 \text { years } \\
\text { Mean: } 73.5\end{array}$ & All married & All unemployed \\
\hline $\begin{array}{l}\text { Focus group discussion- } \\
\text { older female }\end{array}$ & $\begin{array}{l}\text { Range: } 62-70 \text { years } \\
\text { Mean: } 62.43\end{array}$ & All married & All unemployed \\
\hline
\end{tabular}

A 'Mak Bidan' said on the procedure

'It does not matter, if asked I will do but if they prefer hospital it's okay'.

A participant from the male focus group said

'Parents nowadays are busy so they will prefer clinics'

\section{DISCUSSION}

This study found almost everyone had undergone FGC $(99.3 \%)$ at an early age and wanted FGC to continue $(99.3 \%)$ probably because of the non-traumatic nature of the practice and because most respondents believed FGC is compulsory in Islam $(87.6 \%)$ but this is refuted by the Mufti's. This study found a trend in medicalisation.

\section{Prevalence and procedure}

There are no nationally representative data concerning the practice of FGC in Malaysia. ${ }^{2}$ In this study, $99.3 \%$ had undergone FGC which is about the same as another study conducted in Malaysia among women admitted to the labour ward, which found all studied women had undergone FGC. ${ }^{16}$ In Indonesia, the rates range from $43 \%$ to $95 \%{ }^{13}$ There are no official national data in Singapore ${ }^{11}$ and Thailand ${ }^{22}$ but it is believed that most Muslim women in these countries have undergone FGC. In Africa, the rates have been reported from as low as $10 \%$ to as high as $100 \%$, however, the manner and extent of the cutting is vastly different from that performed in SEA. ${ }^{13137}$ The more extreme forms of FGC which include complete excision of the clitoris, removal of large parts of the labia minora and infibulation practised in Africa and the Middle East $^{2}$ is not practised in SEA. ${ }^{22}$ In Malaysia, the tip of the clitoris is nicked using a penknife or razor ${ }^{12} 16$ whereas in Indonesia, it is reported that a very tiny part, as big as a grain of rice, of the clitoris may be removed or simply cut, pricked, scratched or rubbed using a knife, bamboo, thorn, needle, razor or scissors. ${ }^{9} 132235$ In Thailand, a razor blade is used to scratch the tip of the clitoris until a drop of blood is seen. ${ }^{17}$ In Singapore, a thin layer of the membrane on top of the clitoris is cut using scissors. ${ }^{11}$ In all cases, there are no specific guidelines for the procedure.

\section{Age}

Most of the FGC conducted in SEA is done at a very young age. ${ }^{914}$ In Indonesia, FGC usually occurs between the ages of $0-15$ but more commonly the first 40 days of life. ${ }^{131455}$ In Thailand, FGC is performed when the child is very young, usually the first 40 days of life but usually within the first year, however, there is no upper limit to FGC. Adult women who convert may be pressurised to undergo FGC. ${ }^{15}$ In Singapore, like Malaysia, children as young as one or 2 months old undergo FGC. ${ }^{11} 12$ Younger age is preferred because of the believe that the skin is thinner and it is easier to hold down the child and to avoid embarrassment, pain, complications and for quick wound healing. 111231

\section{Medicalisation}

Usually female traditional practitioners who are not medically trained perform FGC without any anaesthesia or sterilisation. ${ }^{2} 1215162126$ Due to campaigns against risky practices in unsanitary conditions, more FGC are being performed by healthcare providers ${ }^{38}$ in clinics in Malaysia, $^{12}$ Indonesia $^{1415}$ and Africa. 221272839 However, WHO is against health professionals performing FGC, worried that medicalisation may legitimise the practice. ${ }^{18}$ Although money is cited as a motivation for healthcare practitioners to practise FGC but some conduct FGC because they consider the practice as a harm reduction process and harmless. However, there are no clear policies, manuals or guidelines dealing with FGC for health practitioners. ${ }^{38}$ There are reports that more of the clitoris is removed in FGC's conducted in clinics as compared with FGC practised by the traditional practitioners. ${ }^{17}$ In Thailand, the practice is still being conducted by traditional practitioners because of the belief that the traditional practitioners are well versed in the religious requirements of the practice. ${ }^{17}$ In Malaysia, more of the practice is being conducted in the clinics by doctors because of the scarcity of the 'Mak Bidans' and because of safety reasons and expertise of the doctors.

\section{Reasons for the practice}

It is believed that FGC was introduced to the region when Islam propagated here. ${ }^{13} 162235$ In Malaysian and other SEA countries, the main reason for the practice is 
religion. ${ }^{12}{ }^{22}$ However, the FGC practised by Catholics, Hindus and Buddhists in Indonesia is because of tradition rather than religion. ${ }^{13}{ }^{14}$ In Indonesia, the traditional practitioners believe that a Muslim must be circumcised otherwise they would not be considered as a Muslim and will not be permitted to attend prayers in the mosque without proper ablution because of uncleanliness and poor hygiene. ${ }^{291435}$ Similarly in Thailand, some believe that female circumcision is obligatory even for women who convert to Islam. In an earlier study in Malaysia, majority of the women interviewed said that a person is not a Muslim if they have not undergone this procedure. Some believe that it is written in the Holy Koran that this procedure is compulsory. ${ }^{12}$ Because of this believe most parents consider it as a parental responsibility and do not consider FGC as a violent or an oppressive act. ${ }^{9}$ In Singapore, the main reason for the practice is also Islam, ${ }^{11}$ here, the Islamic department strongly endorses FGC as part of the Islamic tradition and majority of the religious experts believe that the practice is compulsory for both men and women. ${ }^{11}$ In Thailand, younger Muslim clerics are opposed to the practice because they believe it is not clearly stated in the Koran or in the hadiths. ${ }^{17}$ In Indonesia, some religious experts consider the practice as obligatory but others encourage the practice because it is 'sunah' (recommended) but say there is no obligation to practise it while there are others who believe it is a non-religious custom citing that there is no explicit rule for FGC in the Koran. ${ }^{14}$ But large portions of the Muslim population in Indonesia believe it is 'wajib' (obligatory). ${ }^{1435}$

There are contradictions in the fatwas between religious experts in the region probably because the Koran is silent on FGC. ${ }^{22}$ Although body mutilation is clearly prohibited in Islam, the followers of the Shafi'i school of law consider this practice as wajib (obligatory). The national Ulema (recognised Muslim scholars) council of Indonesia has not issued any fatwa on the subject ${ }^{35}$ but the Al Azhar supreme council of Islamic research in Egypt condemned the practice as having no Islamic law basis and consider it sinful to continue. ${ }^{2527}$

It has been reported that although some in the community may not agree with the practice but they will usually succumb to peer pressure ${ }^{31}$ fearing that society may stigmatise them and not accept them ${ }^{23}$ and render their daughters, not marriageable material. ${ }^{27}$ However, this is not the case in this study, a member of the older women's focus group said 'never took interest in this issue... besides you wouldn't know unless they tell you'.

\section{Continuation of practice}

Many reasons have been cited for the continuation of the practice including the lack of knowledge regarding the health consequences associated with FGC, ${ }^{28}$ religion, ${ }^{31}$ mother's education level ${ }^{33}$ and FGC experience, ${ }^{2}$ fear of ostracism and condemnation ${ }^{37}$ and to gain social acceptance. ${ }^{2}$ Studies in Malaysia and Indonesia have shown that most of the Muslim women wanted the practice to go on and they will continue the practice on their daughters and granddaughters ${ }^{12} 1622$ because they do not see it as harmful to health based on their personal experience. ${ }^{12} 16$ Besides, religion is an important influence for the continuation of the practice. In Indonesia, a letter by the Indonesian Ministry of Health to the doctors and midwives to ban the practice was not supported and instead the religious leaders insisted the practice is obligatory and supported its legalisation and asked for the formation of guidelines and manuals for doctors. ${ }^{14}$

\section{Contradiction in beliefs}

It is seen from this study that that majority in the community believe FGC is a requirement in religion (wajib) whereas the traditional practitioners and more importantly the Mufti's who are responsible in issuing edicts related to religious matters say it is not a religious requirement. Using this information to educate the Muslim community in Malaysia on the true requirements of religion can be an important strategy to eliminate FGC in Malaysia. It is pertinent to keep in mind that a harsh and often overly simplistic and insensitive approach to combating FGC forced on communities that practice it often provokes a backlash and is seen as an attempt to force Western culture and values on them and an attack on their beliefs, identity and religion resulting in defensive and counterproductive reactions from the communities including driving the practice underground with serious consequences. ${ }^{46911122234374041}$

There are several limitations to the study, importantly, the purposive sampling method used which limits the generalisability of the study findings. And because of the dwindling number of traditional midwives, the investigators were forced to limit the number of in-depth interviews to eight. However, the mixed-method design of the study is an advantage considering the qualitative method is able to enrich the findings of the quantitative component.

\section{CONCLUSION AND RECOMMENDATIONS}

The finding of this study which suggests medicalisation of FGC and the insistence of pursuing the practice is troubling. This study found the erroneous belief of the Muslim community that FGC is compulsory in Islam, but this is, however, contradicted by the religious scholars. Because the main reason for the practice is religion and the religious scholars are the people the community trust most on matters related to FGC, this can be a strategy to eliminate the practice in Malaysia. FGC must be looked at beyond just a health issue but a complex interrelated issue involving society, religion, culture and tradition. ${ }^{4}$ Because of the uniqueness of the practice to each region, the interventions should be addressed uniquely involving the community, religious leaders, scholars, practitioners and healthcare providers by way of making the community understand the true requirements of the religion. ${ }^{4} 21222527$ Rather than criminalising the practice outright in Malaysia ${ }^{6}$ culturally sensitive interventions should be put in place with the support of the 
community. ${ }^{34}$ A gradual reduction in the practice using such interventions is a reasonable expectation. Even a slight reduction of the practice can eventually cause reduction or even abandonment of the practice community wide. ${ }^{33}$ The authors suggest more research related to this practice must be encouraged to collect evidence.

Contributors AR and YI were responsible for the study concept and write up. AR was responsible for data analysis.

Funding This study was conducted using the KAKENHI grant (24651289) from Japan Society for the Promotion of Science.

Competing interests None declared.

Patient consent for publication Not required.

Ethics approval The study received the ethical approval from Ritsumeikan Asia Pacific University Research Ethics Committee (AY2016-01).

Provenance and peer review Not commissioned; externally peer reviewed.

Data sharing statement Data are available as online supplementary file.

Open access This is an open access article distributed in accordance with the Creative Commons Attribution Non Commercial (CC BY-NC 4.0) license, which permits others to distribute, remix, adapt, build upon this work non-commercially, and license their derivative works on different terms, provided the original work is properly cited, appropriate credit is given, any changes made indicated, and the use is non-commercial. See: http://creativecommons.org/licenses/by-nc/4.0/.

\section{REFERENCES}

1. Obermeyer CM, Reynolds RF. Female genital surgeries, reproductive health and sexuality: a review of the evidence. Reproductive Health Matters 1999;7:112-20.

2. (UNICEF) UNCsF. Female genital mutilation/cutting: a statistical overview and exploration of the dynamics of change. New York United States of America: Statistics and Monitoring Section,Division of Policy and Strategy, 2013.

3. Dustin M. Female genital mutilation/cutting in the UK. Eur J Women Stud 2010;17:7-23.

4. Elise $\mathrm{R}$, Johansen $\mathrm{B}$, Bathija $\mathrm{H}$, et al. Work of the World Health Organization on female genital mutilation: ongoing research and policy discussions. Finnish Journal of Ethnicity and Migration 2008:3:83-9.

5. Tiilikainen M, Johansson J. Special issue: female genital cutting in the past and today: introduction Finish. Journal of Ethnicity and Migration 2008;3.

6. Arora KS, Jacobs AJ. Female genital alteration: a compromise solution. J Med Ethics 2016;42:148-54

7. Bagnol B, Mariano E. Elongation of the labia minora and use of vaginal products to enhance eroticism: can these practices be considered FGM? Finnish Journal of Ethnicity and Migration 2008;3:42-53.

8. Jeffreys S. Beauty and misogyny: harmful cultural practices in the West. London: Routledge, 2004.

9. Newland L. Female circumcision: muslim identities and zero tolerance policies in rural West Java. Womens Stud Int Forum 2006;29:394-404.

10. Walley CJ. Searching for "voices": feminism, anthropology, and the global debate over female genital operations. Cult Anthropol 1997;12:405-38

11. Marranci G. Female circumcision in multicultural Singapore: The hidden cut. Aust J Anthropol 2015;26:276-92.

12. Rashid A, Patil S, Valimalar A. The practice of female genital mutilation among the rural Malays In North Malaysia. The Internet Journal of Third World Medicine 2009;9:1.

13. Putranti BD, UGMPSKd K. Male and female genital cutting among Javanese and Madurese: collaboration [of] center for population and policy studies: Gadjah Mada University with Australian National University and Ford Foundation, 2003.
14. Putranti BD, Islamize T. Becoming a real woman or commercialized practices? Questioning female genital cutting in Indonesia. Finish Journal of Ethnicity and Migration 2008;3:23-31.

15. Merli C. Male and female genital cutting among Southern Thailand's Muslims: rituals, biomedical practice and local discourses. Cult Health Sex 2010;12:725-38.

16. Rahman A I, Shuib R, Othman MS. The practice of female circumcision among muslims in Kelantan, Malaysia. Reproductive Health Matters 1999;7:137-44.

17. Merli C. Sunat for girls in Southern Thailand: its relation to traditional midwifery, male circumcision and other obstetrical practices. Finnish Journal of Ethnicity and Migration 2008;3:32-41.

18. Organization WH. Female genital mutilation: a joint WHO/UNICEF/ NFPA statement. Geneva: World Health Organization, 1997.

19. Abu-Sahlieh SA. To mutilate in the name of Jehovah or Allah: legitimization of male and female circumcision. Med Law 1994;13:575-622.

20. Toubia N. Female circumcision as a public health issue. $N$ Engl J Med 1994;331:712-6.

21. Okeke T, Anyaehie U, Ezenyeaku C. An overview of female genital mutilation in Nigeria. Ann Med Health Sci Res 2012;2:70-3.

22. Clarence-Smith WG. Islam and female genital cutting in Southeast Asia: The Weight of the Past. Finish Journal of Ethnicity and Migration 2008;3:14-22.

23. Ofor $\mathrm{MO}$, Ofole NM. Female genital mutilation: the place of culture and the debilitating effects on the dignity of the female gender. European Scientific Journal 2015;14:112-21.

24. Mpinga EK, Macias A, Hasselgard-Rowe J, et al. Female genital mutilation: a systematic review of research on its economic and social impacts across four decades. Glob Health Action 2016;9:31489.

25. Gulaid UJ. The challenge of female genital mutilation in Somaliland. Finnish Journal of Ethnicity and Migration 2008;3:90-1.

26. Momoh C. Female genital mutilation. Trends in Urology, Gynaecology \& Sexual Health 2010;15:11-14.

27. Molleman G, Franse L. The struggle for abandonment of Female Genital Mutilation/Cutting (FGM/C) in Egypt. Glob Health Promot 2009;16:57-60.

28. Kaplan A, Hechavarría S, Martín M, et al. Health consequences of female genital mutilation/cutting in the Gambia, evidence into action. Reprod Health 2011;8:26.

29. Putranti BD, Islamize T. Becoming a real woman or commercialized practices? Questioning female genital cutting in Indonesia. Finnish Journal of Ethnicity and Migration 2008;3:23-31.

30. Smith $C$. Creating spaces: challenging conventional discursive norms surrounding the marking of women's bodies. Finnish Journal of Ethnicity and Migration 2008;3:54-63.

31. Kaplan A, Cham B, Njie LA, et al. Female genital mutilation/cutting: the secret world of women as seen by men. Obstet Gynecol Int 2013;2013:1-11.

32. Muteshi JK, Miller S, Belizán JM. The ongoing violence against women: female genital mutilation/cutting. Reprod Health 2016;13:44

33. Wander K. Cultural evolution: Evolution of female genital cutting. Nat Ecol Evol 2017;1:0079.

34. Khaja K, Lay K, Boys S. Female circumcision: toward an inclusive practice of care. Health Care Women Int 2010;31:686-99.

35. Feillard A, Marcoes L. Female circumcision in Indonesia : to " Islamize " in ceremony or secrecy. Archipel 1998;56:337-67.

36. Kontoyannis M, Katsetos C. Female gentital mutilation. Health Science Journal 2010;4:31-6.

37. Organization WH. Eliminating female genital mutilation: an interagency statement. Geneva, Switzerland: World Health Organization, 2008.

38. Department of Reproductive Health and Research WHO. Global strategy to stop health-care providers from performing female genital mutilation. Geneva, Switzerland: World Health Organization, 2010.

39. Yoder PS, Abderrahim N, Zhuzhuni A. Female genital cutting in the demographic and health surveys: a critical and comparative analysis. DHS Comparative Reports No. 7. Calverton, Maryland, USA: ORC Macro, 2004.

40. Gruenbaum E. The female circumcision controversy: an anthropological perspective. Pennsylvania: University of Pennsylvania Press, 2001.

41. Belmaker RH. Successful cultural change: the example of female circumcision among Israeli Bedouins and Israeli Jews from Ethiopia. Isr J Psychiatry Relat Sci 2012;49:178-83. 